\title{
Serological detection of St. Louis encephalitis virus and West Nile virus in equines from Santa Fe, Argentina
}

\author{
Laura Tauro ${ }^{1 /+}$, Betina Marino², Luis Adrian Diaz ${ }^{1,3}$, Eduardo Lucca ${ }^{4}$, \\ Debora Gallozo ${ }^{4}$, Lorena Spinsanti', Marta Contigiani ${ }^{1}$
}

\begin{abstract}
'Laboratorio de Arbovirus y Arenavirus, Instituto de Virología Dr JM Vanella, Facultad de Ciencias Médicas, Universidad Nacional de Córdoba, Enfermera Gordillo Gómez s/n, Córdoba, Argentina ²Cátedra de Virología e Inmunología ${ }^{4}$ Cátedra de Enfermedades Infecciosas, Facultad de Ciencias Veterinarias, Universidad Nacional del Litoral, Santa Fe, Argentina ${ }^{3}$ Carrera del Investigador Científico, Instituto de Investigaciones Biológicas y Tecnológicas, Consejo Nacional de Investigaciones Científicas y Técnicas, Córdoba, Argentina
\end{abstract}

St. Louis encephalitis virus (SLEV) and West Nile virus (WNV) present ecological and antigenic similarities and are responsible for serious human diseases. In addition, WNV is a significant pathogen in terms of equine health. The purpose of our study was to analyse the seroprevalence of SLEV and WNV in equine sera collected in Santa Fe Province, Argentina. The seroprevalence determined using the plaque reduction neutralisation test was $12.2 \%$ for SLEV, $16.2 \%$ for $W N V$ and $48.6 \%$ for a combination of both viruses. These results provide evidence of the cocirculation of SLEV and WNV in equines in Santa Fe.

Key words: SLEV - WNV - horses - PRNT

St. Louis encephalitis virus (SLEV) and West Nile virus (WNV) belong to the Flavivirus genus of the Flaviviridae family; along with the Japanese encephalitis, Cacipacore, Murray Valley encephalitis, Koutango, Usutu and Yaounde viruses, SLEV and WNV constitute the Japanese encephalitis antigenic complex [Index of Viruses. Flaviviridae (2006) (ncbi.nlm.nih.gov/ICTVdb/ Ictv/fs_index.htm)]. SLEV and WNV can cause encephalitis in humans and WNV also causes encephalitis in equines. There is a strong antigenic and epidemiological correlation between these viruses.

SLEV is widely distributed in the Americas (from Canada through Argentina) and serological studies have demonstrated a wide circulation of this virus in temperate and subtropical regions (Sabattini et al. 1998). In the central regions of Argentina, SLEV re-emerged as a human pathogen in 2002 (Spinsanti et al. 2003), with the first epidemic of SLEV human encephalitis occurring in 2005 (Spinsanti et al. 2008). During this outbreak, viral strains belonging to genotype III were isolated from Culex quinquefasciatus mosquitoes (Diaz et al. 2006).

Several species of wild birds of the Ardeidae, Columbidae, Fringillidae, Furnariidae, Icteridae, Tyranidae and Phytotomidae families are infected with this virus in Argentina (Monath \& Heinz 1996, Diaz 2009). The transmission cycles include Cx. quinquefasciatus and

LT is a doctoral student in the Biological Sciences Doctorate Programme (National University of Cordoba) and recipient of a doctoral Scholarship type II from CONICET.

+Corresponding author: laura9505@yahoo.com.ar

Received 5 September 2011

Accepted 15 February 2012
Culex interfor mosquitoes, which act as the primary vectors and Eared doves (Zenaida auriculata) and picui ground-doves (Columbina picui), which serve as the urban vertebrate hosts of SLEV (Diaz 2009).

WNV originated in the Old World and was detected for the first time on the American continent in USA during 1999 (Petersen \& Roehrig 2001). The introduction of this virus was associated with encephalitis outbreaks in humans and massive deaths among birds, particularly Corvidae (Anderson et al. 1999, Nash et al. 2001).

Since 2004, bird and equine infections have been detected from Canada through the northern areas of South America (Komar \& Clark 2006, Bosch et al. 2007). Argentina is one of the few countries outside of USA where WNV strains have been isolated from sick equines and the first records of WNV activity in Argentina were reported in 2006 (Morales et al. 2006); however, seroprevalence studies performed on wild birds confirmed WNV activity at the end of 2004 (Diaz et al. 2008). In Argentina, as elsewhere in the world, WNV is maintained through a bird-mosquito transmission cycle. Although the primary mosquito and avian species involved in WNV transmission are still unknown, $C$. picui could be acting as a host (Diaz et al. 2011).

Other flaviviruses that circulate in Argentina include dengue virus, yellow fever virus, Bussuquara virus (BSQV) and Ilheus virus (ILHV) (Sabattini et al. 1998, Aviles et al. 1999).

The antigenic similarities between different flaviviruses lead to wide cross-reactivity, especially for secondary infections (natural sequential infections by the same or a different flavivirus); this cross-reactivity complicates diagnosis in those regions in which two or more viral species co-circulate. In some cases, higher titres of neutralising antibodies (NTAbs) targeting a specific virus indicate which virus was responsible for the first infection ("original antigenic sin") (Kuno 2003). 
The purpose of the present study was to analyse the natural co-circulation of SLEV and WNV in equines of Santa Fe Province (Argentina) to provide helpful information to allow better interpretation of the serological data obtained from surveillance programmes.

Study site - Santa Fe, located in the central area of Argentina, is divided into 19 counties and has with a total surface of $133.007 \mathrm{~km}^{2}$; the total population exceeds three million inhabitants. The local weather, particularly with regard to temperature and rainfall, constitutes a transition between tropical and temperate climates. The economy is based on agriculture and livestock activities.

Sample collection - Equine (horse) sera from six different counties in Santa Fe were analysed (Figure). All of the samples were obtained between September-November of 2008. The blood samples were collected from the jugular vein of asymptomatic animals and kept at $4^{\circ} \mathrm{C}$ until being processed.

Plaque reduction neutralisation test (PRNT) - NTAb detection was performed using a PRNT with Vero cells (African green monkey kidney cells) (Early et al. 1967) and the serum samples that neutralised at least $80 \%$ of the inoculated viral plaques were considered positive. SLEV strain 78V-6507 obtained from $C x$. quinquefasciatus mosquitoes from Santa Fe and WNV E/7229/06 isolated from sick equines in Buenos Aires were used (Morales et al. 2006). Viral suspensions were prepared using the brains of infected lactating mice and 10\% (weight/volume) minimal essential medium with Earle salts supplemented with L-glutamine, non-essential amino acids, $10 \%$ foetal bovine serum and $1 \%$ antibiotics. The suspensions were centrifuged at $10,000 \mathrm{rpm}$ for $30 \mathrm{~min}$ using a refrigerated centrifuge. Based on new serological evidence provided by Ledermann et al.

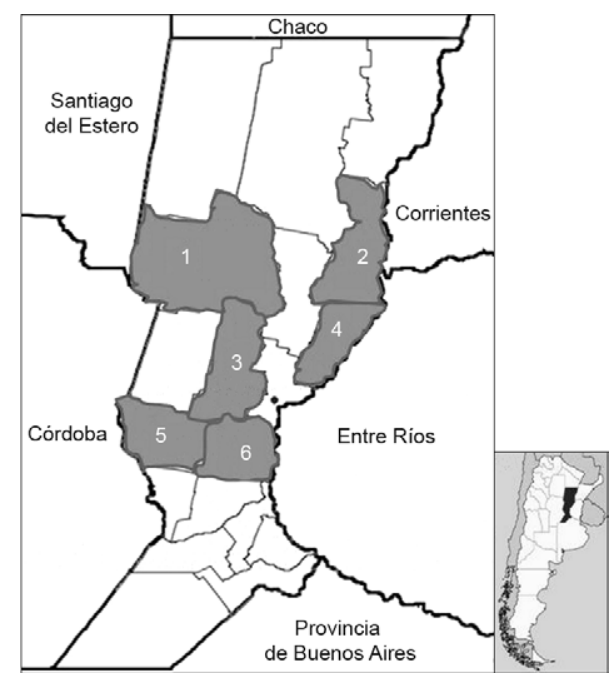

Location of sampling sites in Santa Fe Province, Argentina. 1: San Cristóbal; 2: San Javier; 3: Las Colonias; 4: Garay; 5: San Martin; 6: Sam Jerónimo.
(2011) and Patiris et al. (2008), the serum samples with antibody titres higher than 20 were considered positive for the tested viruses.

All of the samples were also subjected to PRNTs for ILHV (Be H7445) and BSQV (Be AN 4116).

For the statistical analysis, the chi-square test of independence was applied using InfoStat program v. 2010.

A total of 57 of the 74 analysed serum samples were positive for WNV, SLEV or both viruses. The monotypic seroprevalence values were $12.2 \%$ (9/74; titre range 20-1280) for SLEV and $16.2 \%$ (12/74; titre range 20 $640)$ for WNV. In addition, $48.6 \%$ (36/74) of the equines displayed antibodies for both of the viruses (SLEV + WNV) (Table). No significant differences between the prevalence of the viruses were found with respect to the monotypic infections $(\chi 2=1.51 ; p=0.2192)$. All of the sera were negative for ILHV and BSQV.

The prevalence values were not analysed according to the place of origin of the equines due to the scarcity of representative values for most of the sampled locations.

SLEV is endemic in the north-central regions of Argentina, coexisting with the recently introduced WNV (Díaz et al. 2008). Although WNV had been previously isolated from sick and dead equines in Argentina, these cases were all from Buenos Aires; for this reason, the information presented herein is the first record of the equine seroprevalence in Santa Fe, widening the known range of distribution of WNV in Argentina.

During the 1980s, Monath et al. (1985) reported an NTAb screening test that demonstrated an SLEV prevalence of greater than $50 \%$ among equines from different provinces, including Santa Fe; however, there is no recent report of arbovirus circulation in this province.

Our studies found a $12.2 \%$ seroprevalence for SLEV, which is lower than the previously reported values (Monath et al. 1985). The seroprevalence of WNV was similar (16.2\%) and among animals that were positive only for antibodies against WNV, the titres were lower than those detected for SLEV, indicating patterns of primary response. These seroprevalence values could be underestimates due to the alternative criteria of positivity used in the present study.

Forty-eight percent of the analysed samples exhibited serological profiles compatible with a heterotypic serological response. According to the Centers for Disease Control and Prevention's guidelines, a titre difference of $>$ four-fold is used to identify the etiologic agent; when a four-fold difference is not observed, the specific etiological agent cannot be defined (Table). However, this criterion is insufficient to diagnose the etiological agent in some scenarios of arboviral infection; indeed, it is a frequent error to assume that the infecting virus is the one for which higher antibody titres are obtained in two or more dilutions (Kuno 2003). In chickens and equines, Patiris et al. (2008) and Ledderman et al. (2011), respectively, observed that an initial SLEV infection followed by a WNV infection greatly amplified the antibody levels against SLEV, precluding the detection of the subsequent WNV infection using the four-fold titre difference criterion. These authors also demonstrated that crossreaction among heterologous antibodies is not frequent 
in primary infections. Based on these facts, we consider that the infectious agent can indisputably be identified only in monotypic infections. Moreover, we observed that a heterotypic immunological response can be the result of the presence of sequential infections by the same or different viruses (SLEV or WNV) (Table), most often in those animals that presented titres $>160$ for both vi-

TABLE

Heterotypical serological response by plaque reduction neutralisation test (PRNT) against St. Louis encephalitis virus (SLEV) and West Nile virus (WNV) in horse samples collected in Santa Fe Province, Argentina

\begin{tabular}{|c|c|c|c|c|}
\hline \multirow[b]{2}{*}{ Code } & \multicolumn{2}{|c|}{ PRNT (80\%) } & \multicolumn{2}{|c|}{ Interpretation criteria } \\
\hline & SLEV & WNV & CDC's & Alternative \\
\hline 270512 & 160 & 640 & WNV & $\mathrm{SLEV}+\mathrm{WNV}$ \\
\hline 27116 & 20 & 80 & WNV & $\mathrm{SLEV}+\mathrm{WNV}$ \\
\hline 271531 & 160 & 20 & SLEV & SLEV + WNV \\
\hline 270871 & 160 & 640 & WNV & $\mathrm{SLEV}+\mathrm{WNV}$ \\
\hline 271546 & 160 & 20 & SLEV & $\mathrm{SLEV}+\mathrm{WNV}$ \\
\hline 1786 & 80 & 320 & WNV & $\mathrm{SLEV}+\mathrm{WNV}$ \\
\hline 1788 & 80 & 320 & WNV & $\mathrm{SLEV}+\mathrm{WNV}$ \\
\hline 1789 & 80 & 80 & Inconclusive & $\mathrm{SLEV}+\mathrm{WNV}$ \\
\hline 1790 & 1280 & 160 & SLEV & SLEV + WNV \\
\hline 1794 & 20 & 40 & Inconclusive & $\mathrm{SLEV}+\mathrm{WNV}$ \\
\hline 1798 & 640 & 40 & SLEV & $\mathrm{SLEV}+\mathrm{WNV}$ \\
\hline 1799 & 640 & 40 & Inconclusive & SLEV + WNV \\
\hline 1800 & 160 & 80 & Inconclusive & $\mathrm{SLEV}+\mathrm{WNV}$ \\
\hline 1801 & 40 & 1280 & WNV & $\mathrm{SLEV}+\mathrm{WNV}$ \\
\hline 1802 & 20 & 1280 & WNV & $\mathrm{SLEV}+\mathrm{WNV}$ \\
\hline 1812 & 20 & 1280 & WNV & $\mathrm{SLEV}+\mathrm{WNV}$ \\
\hline 1813 & 320 & 160 & Inconclusive & $\mathrm{SLEV}+\mathrm{WNV}$ \\
\hline 1815 & 80 & 1280 & WNV & $\mathrm{SLEV}+\mathrm{WNV}$ \\
\hline 1816 & 20 & 640 & WNV & $\mathrm{SLEV}+\mathrm{WNV}$ \\
\hline 1817 & 20 & 20 & Inconclusive & Inconclusive \\
\hline 1818 & 80 & 20 & SLEV & $\mathrm{SLEV}+\mathrm{WNV}$ \\
\hline 1819 & 80 & 640 & WNV & $\mathrm{SLEV}+\mathrm{WNV}$ \\
\hline 1826 & 20 & 1280 & WNV & $\mathrm{SLEV}+\mathrm{WNV}$ \\
\hline 1827 & 80 & 160 & Inconclusive & $\mathrm{SLEV}+\mathrm{WNV}$ \\
\hline 1828 & 20 & 20 & Inconclusive & Inconclusive \\
\hline 1831 & 20 & 80 & WNV & $\mathrm{SLEV}+\mathrm{WNV}$ \\
\hline 41 & 20 & 20 & Inconclusive & Inconclusive \\
\hline 43 & 160 & 160 & Inconclusive & $\mathrm{SLEV}+\mathrm{WNV}$ \\
\hline 40 & 20 & 20 & Inconclusive & Inconclusive \\
\hline 19 & 20 & 20 & Inconclusive & Inconclusive \\
\hline 27 & 20 & 80 & WNV & $\mathrm{SLEV}+\mathrm{WNV}$ \\
\hline 23 & 80 & 20 & SLEV & $\mathrm{SLEV}+\mathrm{WNV}$ \\
\hline 10 & 20 & 20 & Inconclusive & Inconclusive \\
\hline 8 & 640 & 80 & SLEV & $\mathrm{SLEV}+\mathrm{WNV}$ \\
\hline 35 & 640 & 1280 & Inconclusive & $\mathrm{SLEV}+\mathrm{WNV}$ \\
\hline 12 & 640 & 320 & Inconclusive & SLEV + WNV \\
\hline
\end{tabular}

CDC: Centers for Disease Control and Prevention. ruses or in animal infected with another antigenically related flavivirus (i.e., sample numbers 1789, 1817, 1828 and 41) (Table). Ledermann et al. (2011) reported high titres of antibodies (160-1280) with considerable crossreactions and a highly heterogeneous response in more than $70 \%$ of the equines previously inoculated with SLEV and then challenged with SLEV or WNV.

These results demonstrate the difficulties encountered in the interpretation of the data and showed that the equines had been exposed to both viruses, with high levels of high cross-reactivity. Thus, the analysis of a single sample may provide misleading or inaccurate results regarding the etiologic agent, underscoring the importance of the timing of sample collection and of multiple-sample testing. To better estimate the level of recent circulation of these viruses in the future, surveillance should be based on IgM assays.

In conclusion, the circulation of more than one flavivirus in Santa Fe indicates that the surveillance of these infectious agents in Argentina should be intensified.

\section{ACKNOWLEDGEMENTS}

To the Laboratories of Private Veterinary Diagnosis, CEDIVA and Rioagro SRL L 104, for their assistance in the performance of this study.

\section{REFERENCES}

Anderson JF, Andreadis TG, Vossbrinck CR, Tirrell S, Wakem, EM, French RA, Garmendia AE, Van Kruiningen HJ 1999. Isolation of West Nile virus from mosquitoes, crows and a Cooper's hawk in Connecticut. Sciencie 286: 2331-2333.

Aviles G, Rangeon G, Voendam V, Briones A, Baroni P, Enria D, Sabattini M 1999. Dengue reemergence in Argentina. Emerg Infect Dis 5: 575-578.

Bosch I, Herrera F, Navarro JC, Lentino M, Dupuis A, Maffei J, Jones M, Fernández E, Pérez N, Pérez-Emán J, Guimarães AE, Barrera R, Valero N, Ruiz J, Velásquez G, Martinez J, Comach G, Komar N, Spielman A, Kramer L 2007. West Nile virus. Emerg Infect Dis 13: 651-653.

Diaz LA 2009. Patrones de actividad y estacionalidad del virus St. Louis encephalitis (Flavivirus, Flaviviridae) en la ciudad de Córdoba, Argentina, PhD Thesis, Universidad Nacional de Córdoba, Córdoba, 250 pp.

Diaz LA, Komar N, Visintin A, Dantur Juri MJ, Stein M, Lobo Allende R, Spinsanti L, Konigheim B, Aguilar J, Laurito M, Almirón W, Contigiani M 2008. West Nile virus in birds, Argentina. Emerg Infect Dis 14: 689-691.

Diaz LA, Nemeth NM, Bowen RA, Almirón WR, Contigiani MS 2011. Comparison of argentinean Saint Louis encephalitis virus non-epidemic and epidemic strain infections in an avian model. PLoS Negl Trop Dis 5: 1177.

Diaz LA, Ré V, Almirón WR, Farías A, Vázquez A, Sanchez-Seco P, Aguilar J, Spinsanti L, Konigheim B, Visintin A, Garciá J, Morales MA, Tenorio A, Contigiani M 2006. Genotype III Saint Louis encephalitis virus outbreak, Argentina, 2005. Emerg Infect Dis 12: 1752-1754.

Early E, Peralta Ph, Johnson KM 1967. A plaque neutralization method for arboviruses. Proc Soc Exp Biol 25: 741-747.

Komar N, Clark GG 2006. West Nile virus activity in Latin America and the Caribbean. Rev Panam Salud Publica 19: 112-117.

Kuno G 2003. Serodiagnosis of flaviviral infections and vaccination in humans. Adv Virus Res 61: 3-65. 
Ledermann J, Lorono-Pino M, Ellis C, Shaw K, Blitvich B, Beaty B, Bowen R, Powers A 2011. The evaluation of widely used diagnostic test to detect West Nile virus infections with St. Louis encephalitis or dengue virus. Clin Vaccine Inmunol 18: 580-587.

Monath TP, Heinz F 1996. Flaviviruses. In BN Fields, DM Knipe, PM Howley, RM Chanock, JL Melnick, TP Monath (eds.), Fields virology, Vol. 1, 3rd ed., Lippincott-Raven, Philadelphia, p. 961-984.

Monath TP, Sabattini MS, Pauli R, Daffner JF, Mitchell CJ, Bowen GS, Cropp CB 1985. Arbovirus investigations in Argentina, 1977-1980. IV. Serologic surveys and sentinel equine program. Arthropod collections and virus isolations from argentine mosquitoes. Am J Trop Med Hyg 34: 945-955.

Morales MA, Barrandeguy M, Fabbri C, Garcia JB, Vissani A, Trono K, Gutierrez G, Pigretti S, Menchaca H, Garrido N, Taylor N, Fernández F, Levis S, Enría D 2006. West Nile virus isolation from equines in Argentina, 2006. Emerg Infect Dis 12: $1559-1561$

Nash D, Mostashari F, Fine A, Miller J, O'Leary D, Murray K, Huang A, Rosenberg A, Greenberg A, Sherman M, Wong S, Layton M 2001. The outbreak of West Nile virus infection in the New York City area in 1999. N Engl J Med 344: 1807-1814.
Patiris PJ, Oceguera LF, Peck GW, Chiles RE, Reisen WK, Hanson CV 2008. Serologic diagnosis of West Nile and St. Louis encephalitis virus infections in domestic chickens. Am J Trop Med Hyg 78: 434-441.

Petersen LR, Roehrig JT 2001. West Nile virus: a reemerging global pathogen. Emerg Infect Dis 7: 208-216.

Sabattini MS, Avilés G, Monath TP 1998. Historical, epidemiological and ecological aspects of arbovirus in Argentina: Flaviviridae, Bunyaviridae and Rhabdoviridae. In APA Travassos da Rosa, PFC Vasconcelos, JFS Travassos da Rosa (eds.), An overview of arbovirology in Brazil and neighboring countries, Instituto Evandro Chagas, Belém, p. 113-134.

Spinsanti L, Basquiera A, Bulacio S, Kim S, Somale V, Ré V, Rabbat D, Zarate A, Zlocowski JC, Quiroga Mayor C, Contigiani M, Palacios S 2003. St. Louis encephalitis in Argentina: the first case reported in the last seventeen years. Emerg Infect Dis 9: 271-273.

Spinsanti L, Diaz LA, Glatstein N, Arselán S, Morales MA, Farías A, Fabbri C, Aguilar J, Ré V, Frías M, Almiron W, Hunsperger E, Siirin M, Travassos da Rosa A, Tesh R, Enría D, Contigiani M 2008. Human outbreak of St. Louis encephalitis detected in Argentina, 2005. J Clin Virol 42: 27-33. 